\title{
PENINGKATAN SIKAP POSITIF IBU-IBU WALI PAUD TERHADAP PEMBELAJARAN DI PAUD RW II TAMBAK WEDI SURABAYA
}

\author{
Dewi Mustami'ah ${ }^{1}$, Andi Maulida Rahmania' ${ }^{1}$, Anisa Nilasari ${ }^{2}$ \\ ${ }^{1}$ Dosen Fakultas Psikologi, Universitas Hang Tuah Surabaya \\ ${ }^{2}$ Laboran Psikologi Perkembangan dan Pendidikan, Fakultas Psikologi Universitas Hang Tuah Surabaya \\ Jl A. Rahman Hakim 150 Surabaya 60111, Telepon: (031) 5945864
}

\section{RINGKASAN}

\section{Pelatihan Pentingnya Belajar Anak Usia Dini di RW II Tambak Wedi Surabaya}

Tujuan dari kegiatan pengabdian kepada masyarakat ini adalah untuk membentuk sikap positif ibu-ibu wali murid PAUD RW II Kelurahan Tambak Wedi Surabaya terhadap pembelajaran di PAUD. Permasalahan selama ini ibuibu menganggap pembelajaran di PAUD kurang ada manfaatnya karena hanya diajari bernyanyi, berjalan-jalan dan bermain saja. Sedangkan orang tua menghendaki ketika anak dimasukkan PAUD akan diajari menulis, berhitung dan membaca. Akibatnya orang tua terkadang tidak akan mengantarkan anaknya ketika sibuk atau punya aktifitas lain dan bahkan akan menghentikan anaknya ditengah tahun pelajaran. Anak tidak sampai tuntas mengikuti pembelajaran di PAUD sampai akhir tahun pelajaran. Dalam upaya meningkatkan sikap positif orang tua (ibu) pada pentingnya belajar di PAUD, maka diperlukan pemahaman terhadap orang tua melalui Focus Group Discussion tentang belajar anak PAUD, Belajar Bersama Anak melalui aktifitas ibu-anak. Untuk meningkatkan sikap positif ibu terhadap PAUD diperlukan pemahaman tentang perkembangan anak Usia Dini, Model belajar anak usia dini, pemilihan stimulant yang cocok untuk anak usia dini. Diharapkan dengan pemahaman yang tepat tentang Pendidikan anak usia dini orang tua akan memiliki sikap positif terhadap PAUD, sehingga orang tua akan berpartisipasi aktif dalam pembelajaran anak. Hasil Ibu-Ibu lebih memahami Pendidikan PAUD mengembangkan aspek fisik, panca indera, emosi, social, pengetahuan, agama pada anak melalui metode bermain. Sehingga ketika bunda PAUD mengajak anak-anak melompat-lompat, berlari atau berjalan-jalan, sebenarnya didalamnya terdapat pengetahuan berbaris, sabar menunggu aba-aba, mengerti teman di kanan kirinya, melatih kepekaan anak dalam mendengar perintah. Ibu-ibu juga memiliki pemahaman terkait bagaimana harus menghadapi anak-anak usia dini dan perilaku khasnya seperti senang berlarian, coret-coret dan ibu-ibu juga memiliki pandangan bagaimana mengelola emosi dengan lebih baik saat menghadapi anak. Ibu-ibu memperoleh gambaran stimulasi anak usia dini yang dapat dilakukan ibu dan anak di rumah dengan menggunakan bahan-bahan yang sederhana namun bertujuan untuk melatih kemampuan sensorik anak, yaitu kegiatan meremas kertas, dan menempel benda-benda kecil di kertas (misalnya biji-bijian (jagung, kedelai, beras, kacang-kacangan)).

Kata kunci: Sikap ibu terhadap PAUD, Pendidikan Usia Dini, Focus Group Discussion

\begin{abstract}
The purpose of this community service activity is to establish a positive attitude towards the guardians of PAUD RW II students in Tambak Wedi Surabaya Village towards learning in PAUD. The problem so far has been that mothers consider learning in PAUD to be of no use because they are only taught to sing, walk and play. Whereas parents want PAUD when children are included, they will be taught to write, count and read. As a result parents sometimes will not deliver their children when they are busy or have other activities and will even stop their children in the middle of the school year. Children do not complete learning in PAUD until the end of the school year. In an effort to improve the positive attitude of parents (mothers) on the importance of learning in PAUD, it is necessary to understand parents through Focus Group Discussion on PAUD children's learning, Learning With Children through mother-child activities. To improve the mother's positive attitude towards PAUD, an understanding of Early Childhood development, early childhood learning model, selection of stimulants suitable for early childhood is needed. It is expected that with proper understanding of early childhood education parents will have a positive attitude towards PAUD, so parents will actively participate in children's learning. Results Mothers better understand PAUD education develops physical aspects, senses, emotions, social, knowledge, religion in children through playing methods. So when the mother of PAUD invites children to jump around, run or walk, in fact there is a lined up knowledge, patiently waiting for the cue, understanding the friend on her left and training the child in listening to commands. Mothers also have
\end{abstract}


an understanding of how to deal with early childhood and their typical behaviors such as running around, scribbling and mothers also have a view on how to manage emotions better when facing children. Mothers get a picture of early childhood stimulation that can be done by mothers and children at home by using simple ingredients but aims to train children's sensory abilities, namely the activity of squeezing paper, and sticking small objects on paper (for example, grains (corn, soybeans, rice, nuts).

Keywords: Maternal attitudes toward PAUD, Early Age Education, Focus Group Discussion

\section{PENDAHULUAN}

Usia dini merupakan usia yang paling tepat untuk memperoleh berbagai stimulus, baik yang bersifat untuk mengembangkan aspek fisik, kognitif, afeksi dan sosial. Orang tua memiliki peran yang penting untuk memberikan pendidikan dengan cara memberikan stimulasi pada anak usia dini. Hal tersebut sesuai dengan pendapat Morisson (1988) bahwa Peran serta orangtua dalam pendidikan itu sendiri dapat diwujudkan dalam berbagai bentuk aktivitas yang dilakukan orangtua, baik di rumah ataupun di sekolah, sehingga akan memberikan keuntungan baik bagi orangtua, anak maupun sekolah. Hal tersebut didukung oleh pendapat Mansyur (2005) bahwa orang tua memiliki peran dalam pendidikan pada setiap jenjang pendidikan terlebih lagi pada lembaga PAUD, karena anak baru memulai pembentukan karakter melalui pengembangan sikap, moral, agama, sosial dan emosional.

Kenyataannya ketika anak masuk PAUD orang tua menuntut anaknya untuk bisa membaca, menulis dan berhitung. Orang tua menganggap anaknya di PAUD hanya main-main saja, bahkan ada yang menganggap anaknya menjadi nakal setelah masuk PAUD. Padahal menurut Adilla (2010) bahwa pendidikan anak usia dini merupakan salah satu bentuk penyelenggaraan pendidikan yang menitikberatkan pada peletakan dasar ke arah pertumbuhan dan perkembangan fisik (koordinasi motorik halus dan kasar), kecerdasan (daya pikir, daya cipta, kecerdasan emosi, kecerdasan spiritual), sosio emosional (sikap dan perilaku serta agama) bahasa dan komunikasi, sesuai dengan keunikan dan tahap-tahap perkembangan yang dilalui oleh anak usia dini. Dan juga pendapat Hasan (2009) PAUD merupakan salah satu bentuk penyelenggaraan pendidikan yang menitikberatkan pada peletakan dasar ke arah pertumbuhan dan perkembangan fisik dan kecerdasan, daya pikir, daya cipta, emosi, spiritual, berbahasa/komunikasi, dan sosial.

Berdasarkan hal tersebut di atas peneliti tertarik untuk mengetahui bagaimana sikap orang tua, utamanya ibu pada PAUD RW 2 di Tambak Wedi Surabaya. RW 2 Tambak Wedi Surabaya merupakan daerah yang ada didekat laut dekat Jembatan Suramadu. Daerah ini sebagian besar warganya bekerja sebagai nelayan. PAUD di RW 2 Tambak Wedi masuk sore mulai jam 16.00 sampai dengan 17.30 menyesuaikan dengan kegiatan warganya. Informasi yang diperoleh oleh peneliti dari penuturan guru PAUD diantaranya adalah kurangnya pengetahuan ibu-ibu yang memiliki anak usia dini tentang pentingnya pendidikan bagi anak usia dini. Ibu-ibu RW II banyak yang memiliki anggapan bahwa anak yang mengikuti PAUD non formal tidak banyak mendapat berbagai pembelajaran seperti membaca maupun menulis, karena di PAUD non formal lebih banyak kegiatan bermain, mewarnai maupun menggambar. Anggapan yang dimiliki ibu-ibu tersebut membuat mereka tidak konsisten mengantar anak mereka ke PAUD sesuai jadwal, bahkan tidak sedikit ibu-ibu yang memutuskan untuk berhenti mengikuti PAUD dan menunggu hingga pembelajaran di Taman Kanak-Kanak yang merupakan PAUD formal dimulai dan masuk ke TK tersebut tanpa melalui proses wisuda dari PAUD nonformal yang sudah diikuti.

\section{Identifikasi dan Rumusan Masalah}

Berdasarkan uraian masalah di atas, kami tertarik untuk mengetahui bagaimana sikap orang tua, utamanya ibu pada PAUD RW 2 di Tambak Wedi Surabaya. RW2 Tambak Wedi Surabaya merupakan daerah yang ada didekat laut dekat Jembatan Suramadu. Daerah ini sebagian besar warganya bekerja sebagai nelayan. PAUD di RW2 Tambak Wedi masuk sore mulai jam 16.00 sampai dengan 17.30 menyesuaikan dengan kegiatan warganya. Informasi yang diperoleh oleh peneliti dari penuturan guru PAUD diantaranya adalah kurangnya pengetahuan ibu-ibu yang memiliki anak usia dini tentang pentingnya pendidikan bagi anak usia dini. Ibu-ibu RW II banyak yang memiliki anggapan bahwa anak yang mengikuti PAUD non formal tidak banyak mendapat berbagai pembelajaran seperti membaca maupun menulis, karena di PAUD non formal lebih banyak kegiatan bermain, mewarnai maupun menggambar. Anggapan yang dimiliki ibu-ibu tersebut membuat mereka tidak konsisten mengantar anak mereka ke PAUD sesuai jadwal, bahkan tidak sedikit ibu-ibu yang memutuskan untuk berhenti mengikuti PAUD dan menunggu hingga pembelajaran di Taman Kanak-Kanak yang merupakan PAUD formal dimulai dan masuk ke TK tersebut tanpa melalui proses wisuda dari PAUD nonformal yang sudah diikuti.

Berdasarkan uraian tersebut di atas diperlukan data untuk mengetahui deskripsi sikap ibu terhadap pendidikan Anak Usia Dini dan upaya pelibatan aktif orang tua dalam Pendidikan anak di PAUD. 


\section{TINJAUAN PUSTAKA}

\section{Sikap Terhadap Pendidikan Anak Usia Dini}

Thrustone mendefinisikan sikap sebagai derajat afek positif atau afek negatif terhadap suatu obyek psikologis (Azwar, 2007). Sedangkan menurut Menurut Fishben \& Ajzen, sikap sebagai predisposisi yang dipelajari untuk merespons secara konsisten dalam cara tertentu berkenaan dengan objek tertentu. Sherif \& Sherif menyatakan bahwa sikap menentukan keajegan dan kekhasan perilaku seseorang dalam hubungannya dengan stimulus manusia atau kejadian-kejadian tertentu.

Azwar (2007), menggolongkan definisi sikap dalam tiga kerangka pemikiran. Pertama, kerangka pemikiran yang diwakili oleh para ahli psikologi seperti Louis Thurstone, Rensis Likert dan Charles Osgood. Menurut mereka sikap adalah suatu bentuk evaluasi atau reaksi perasaan. Sikap seseorang terhadap suatu objek adalah perasaan mendukung atau memihak (favorable) maupun perasaan tidak mendukung atau tidak memihak (unfavorable) pada objek tersebut. Kedua, kerangka pemikiran ini diwakili oleh ahli seperti Chave, Bogardus, LaPierre, Mead dan Gordon Allport. Menurut kelompok pemikiran ini sikap merupakan semacam kesiapan untuk bereaksi terhadap suatu objek dengan cara-cara tertentu. Kesiapan yang dimaksud merupakan kecenderungan yang potensial untuk bereaksi dengan cara tertentu apabila individu dihadapkan pada suatu stimulus yang menghendaki adanya respons.

Ketiga, kelompok pemikiran ini adalah kelompok yang berorientasi pada skema triadik (triadic schema). Menurut pemikiran ini suatu sikap merupakan konstelasi komponen kognitif, afektif dan konatif yang saling berinteraksi didalam memahami, merasakan dan berperilaku terhadap suatu objek. Jadi berdasarkan definisi di atas, dapat disimpulkan bahwa sikap adalah kecenderungan individu untuk memahami, merasakan, bereaksi dan berperilaku terhadap suatu objek yang merupakan hasil dari interaksi komponen kognitif, afektif dan konatif.

Azwar (2007) menyatakan bahwa sikap memiliki 3 komponen yaitu: a. Komponen kognitif, Komponen kognitif merupakan komponen yang berisi kepercayaan seseorang mengenai apa yang berlaku atau apa yang benar bagi objek sikap; b. Komponen afektif, Komponen afektif merupakan komponen yang menyangkut masalah emosional subjektif seseorang terhadap suatu objek sikap. Secara umum, komponen ini disamakan dengan perasaan yang dimiliki terhadap sesuatu; c. Komponen perilaku, Komponen perilaku atau komponen konatif dalam struktur sikap menunjukkan bagaimana perilaku atau kecenderungan berperilaku yang ada dalam diri seseorang berkaitan dengan objek sikap yang dihadapinya.

Werner dan Defleur (Azwar, 2007) mengemukakan 3 postulat guna mengidentifikasikan tiga pandangan mengenai hubungan sikap dan perilaku, yaitu postulat of consistency, postulat of independent variation, dan postulate of contingent consistency. Postulat Konsistensi mengatakan bahwa sikap verbal memberi petunjuk yang cukup akurat untuk memprediksikan apa yang akan dilakukan seseorang bila dihadapkan pada suatu objek sikap. Sedangkan Postulat Variasi Independen menjelaskan bahwa mengetahui sikap tidak berarti dapat memprediksi perilaku karena sikap dan perilaku merupakan dua dimensi dalam diri individu yang berdiri sendiri, terpisah dan berbeda. Postulat Konsistensi Kontigensi menyatakan bahwa hubungan sikap dan perilaku sangat ditentukan oleh faktor-faktor situasional tertentu. Norma-norma, peranan, keanggotaan kelompok dan lain sebagainya, merupakan kondisi ketergantungan yang dapat mengubah hubungan sikap dan perilaku.

Sehubungan dengan hal tersebut di atas, maka prediksi perilaku dapat disandarkan pada sikap akan berbeda dari waktu ke waktu dan dari satu situasi ke situasi lainnya. Postulat Konsistensi Kontingensi menjelaskan hubungan sikap dan perilaku, yaitu apabila individu berada dalam situasi yang betul-betul bebas dari berbagai bentuk tekanan atau hambatan yang dapat mengganggu ekspresi sikapnya maka dapat diharapkan bahwa bentuk-bentuk perilaku yang ditampakkannya merupakan ekspresi sikap yang sebenarnya. Artinya, potensi reaksi sikap yang sudah terbentuk dalam diri individu itu akan muncul berupa perilaku aktual sebagai cerminan sikap yang sesungguhnya terhadap sesuatu. Sebaliknya jika individu mengalami atau merasakan hambatan yang dapat mengganggu kebebasannya dalam mengatakan sikap yang sesungguhnya atau bila individu merasakan ancaman fisik maupun ancaman mental yang dapat terjadi pada dirinya sebagai akibat pernyataan sikap yang hendak dikemukakan maka apa yang diekspresikan oleh individu sebagai perilaku lisan atau perbuatan itu sangat mungkin tidak sejalan dengan sikap hati nuraninya, bahkan dapat sangat bertentangan dengan apa yang dipegangnya sebagai suatu keyakinan. Semakin kompleks situasinya dan semakin banyak faktor yang menjadi pertimbangan dalam bertindak maka semakin sulitlah memprediksikan perilaku dan semakin sulit pula menafsirkannya sebagai indikator (Azwar, 2007).

\section{Pendidikan Anak Usia Dini}

Berdasarkan Undang-undang Nomor 20 tahun 2003 tentang Sistem Pendidikan Nasional yang dimaksud Anak Usia Dini adalah kelompok manusia yang berusia 0-6 tahun (Depdiknas, 2002). Anak usia dini adalah kelompok anak yang berada dalam proses pertumbuhan dan perkembangan yang bersifat unik, dalam arti memiliki pola pertumbuhan dan perkembangan (koordinasi motorik halus dan kasar), intelegensi (daya pikir, daya cipta, kecerdasan emosi, dan kecerdasan spiritual), sosial emosional (sikap dan perilaku serta agama), bahasa 
dan komunikasi yang khusus sesuai dengan tingkat pertumbuhan dan perkembangan anak.

Menurut Hasnidah (2014) Pendidikan Anak Usia Dini (PAUD) adalah jenjang pendidikan sebelum jenjang pendidikan dasar yang merupakan suatu upaya pembinaan yang ditujukan bagi anak sejak lahir sampai dengan usia enam tahun yang dilakukan melalui pemberian rangsangan pendidikan untuk membantu pertumbuhan dan perkembangan jasmani dan rohani agar anak memiliki kesiapan dalam memasuki pendidikan lebih lanjut, yang diselenggarakan pada jalur formal, non formal, dan informal. Sedangkan menurut Sujiono (2011) Pendidikan anak usia dini adalah meliputi upaya dan tindakan yang dilakukan oleh pendidik dan orangtua dalam proses perawatan, pengasuhan, dan pendidikan pada anak.

Perkembangan anak usia dini sebenarnya dimulai Sejak pranatal. Usia dini merupakan usia yang sangat penting bagi perkembangan anak sehingga disebut golden age. Setelah lahir, sel-sel otak mengalami mielinasi dan membentuk jalinan yang kompleks, sehingga nantinya anak bisa berpikir logis dan rasional. Selain otak, organ sensoris seperti pendengar, penglihatan, penciuman, pengecap, perabaan, organ keseimbangan juga berkembang pesat (Gardner, 1993).

Hasenstab dan Horner (1982) mengatakan bahwa pendidikan anak usia dini dimulai tiga tahun sampai dengan enam tahun yang sering dikatakan sebagai Pendidikan prasekolah, dan pada masa ini anak mengalami perkembangan yang sangat pesat baik fisik, maupun psikis atau kejiwaan.

2. Peran Orang Tua Dalam Pendidikan Anak Usia Dini Menurut Anwar dan Ahmad (2009), peran orangtua dalam pendidikan anak usia dini yaitu: a) Orangtua sebagai guru pertama dan utama; b) Mengembangkan kreativitas anak; c) Meningkatkan kemampuan otak anak; dan d) Mengoptimalkan potensi anak. Sedangkan Grotberg (1979) mengemukakan bahwa tugas orangtua (Parental Role) dalam hubungannya dengan proses pendidikan anak adalah memberikan stimulasi edukasi (educational stimulation) dan dukungan emosi (emotional support). Stimulasi edukasi adalah pemberian kesempatan pada anak untuk dapat mengembangkan potensi dirinya baik secara emosional maupun intelektual, penyediaan sarana dan prasarana belajar, seperti buku-buku, alat permainan, serta pemberian kesempatan bagi anak untuk dapat bereksplorasi pada lingkungan yang lebih luas. Dukungan emosi dimaksudkan sebagai hubungan interpersonal antara anak dan orang tua.

3. Sikap Orang Tua terhadap Pendidikan Anak Usia Dini Thrustone mendefinisikan sikap sebagai derajat afek positif atau afek negatif terhadap suatu obyek psikologis (Azwar, 2007). Berdasarkan pendapat Werner dan Defleur
(Azwar, 2007) tentang Postulat Konsistensi Kontingensi, bahwa hubungan sikap dan perilaku sangat ditentukan oleh faktor-faktor situasional tertentu. Norma-norma, peranan, keanggotaan kelompok dan lain sebagainya, merupakan kondisi ketergantungan yang dapat mengubah hubungan sikap dan perilaku.

Sehubungan dengan sikap ibu terhadap PAUD, maka apabila ibu-ibu dalam kondisi tidak banyak pekerjaan maka dapat menganggap PAUD merupakan penting, sehingga ia akan mengantarkan anaknya ke balai RW untuk belajar bersama teman-temannya. Sedangkan jika ibu-ibu tersebut dalam situasi repot, ia menganggap memasukkan anak ke PAUD menambah pekerjaan karena harus mengantar atau bahkan menunggui anaknya. Akibatnya ketika ibu-ibu ada kerjaan atau sibuk anak tidak akan diantar ke PAUD. Dan jika ibu-ibu ditanya akan menjawab PAUD penting, namun belum tentu akan diwujudkan ke perilakunya untuk bersedia mengantarkan anaknya untuk belajar di PAUD. Orang tua menyatakan saying pada anaknya, namun ketika ibunya emosi anak bisa menjadi sasaran emosinya, dan ibu akan menyesal setelah ia habis memarahi anaknya.

\section{METODE}

Pelaksanaan kegiatan pengabdian di Balai RW II Kelurahan Tambak Wedi Surabaya. Pengabdian masyarakat ini ditujukan kepada 33 ibu sebagai wali murid dari PAUD RW II Tambak Wedi Surabaya.

Kegiatan berupaya 1) Penyuluhan pentingnya Pendidikan Usia Dini disertai dengan Focus Group Discussion (peserta dibagi menjadi dua kelompok), peserta diberikan kesempatan bertanya terkait situasi yang sering dihadapi namun belum dapat diatasi secara tepat. Diantaranya, bagaimana jika anak suka berlarian di malam hari, bagaimana jika anak tidak mau tidur siang, bagaimana jika anak maunya coretcoret saja dan tidak mau belajar menulis dengan benar, bagaimana jika ibu belum dapat mengelola emosi ketika anak melakukan hal-hal yang tidak diinginkan dan bagaimana jika anak tidak mau menuruti perintah Ibu. Konselor menjawab pertanyaan-pertanyaan peserta dengan memberikan informasi terkait kapasitas belajar anak usia dini, karakteristik anak usia dini dalam belajar, tujuan belajar di PAUD dan apa yang perlu dilakukan ibu saat memiliki anak-anak usia dini. 2) Kegiatan kerjasama ibu dan anak. Kegiatan ini memberikan gambaran stimulasi anak usia dini yang dapat dilakukan ibu dan anak di rumah dengan menggunakan bahan-bahan yang sederhana namun bertujuan untuk melatih kemampuan sensorik anak, yaitu kegiatan meremas kertas, dan menempel benda-benda kecil di kertas. 


\section{HASIL DAN PEMBAHASAN}

Berdasarkan hasil tanya jawab diketahui ibu-ibu menjadi paham:

a. Pendidikan PAUD mengembangkan aspek fisik, panca indera, emosi, sosial, pengetahuan, agama pada anak melalui metode bermain. Sehingga ketika bunda PAUD mengajak anak-anak melompat-lompat, berlari atau berjalan-jalan, sebenarnya didalamnya terdapat pengetahuan berbaris, sabar menunggu aba-aba, mengerti teman di kanan kirinya, melatih kepekaan anak dalam mendengar perintah.

b. Anak PAUD yang rata-rata usia 3 sampai 4 tahun perilaku khasnya seperti senang berlarian, coret-coret, banyak bertanya dan suka menirukan apa yang dilihat dan didengar.

c. Anak PAUD juga masih belum memahami bahasa secara lengkap. Orang tua perlu pelan-pelan ketika mengajak bicara anak-anaknya. Orang tua perlu mengajak cerita sehingga anak akan berkembang pengetahuannya dengan bertanya dan menirukan cerita orang tuanya.

d. Ibu-ibu juga memiliki pandangan bagaimana mengelola emosi dengan lebih baik saat menghadapi anak.

Kegiatan kerjasama ibu dan anak, memberikan gambaran stimulasi anak usia dini yang dapat dilakukan ibu dan anak di rumah dengan menggunakan bahan-bahan yang sederhana namun bertujuan untuk melatih kemampuan sensorik anak, yaitu kegiatan meremas kertas, dan menempel benda-benda kecil (biji-bijian) di kertas.

Orang tua dibiasakan memberi kepercayaan kepada anak bahwa anak bisa mengerjakan tugas sendiri dan ibu bertugas memberi dukungan dan memberi arahan jika diperlukan. Orang tua dibiasakan menghargai karya anak apapun bentuknya. Penghargaan ibu bisa berupa pujian dengan kata "Bagus, gambarmu" anak akan termotivasi untuk mengerjakan lagi.

\section{Hasil Kuesioner Sikap Ibu terhadap PAUD}

1. Berdasarkan tingkat pendidikan diketahui bahwa 33 ibu wali murid PAUD didominasi lulusan SMP atau SMA (17 orang/51.52\%), tidak sekolah atau tamat SD (14 orang/42.42\%) dan yang tamat perguruan tinggi ( 2 orang/6.06\%). Berdasarkan data tersebut diharapkan dengan adanya penyuluhan tentang pentingnya belajar di PAUD akan mudah dipahami dan nantinya dapat ditindaklanjuti.

2. Penghasilan keluarga rata-rata per bulan paling dominan adalah lebih dari Rp 2.000.000 (14 orang/38.9\%), Rp 500.000.00-, sampai dengan 1.000.000.00-, (10 orang/30.030\%) yaitu sebaya, pendapatan Rp 1.000 .000 - Rp 1.500.000 (6 orang/16.7\%) dan Rp 1.500.000 - Rp 2.000 .000 (2 orang $/ 5.6 \%)$. Berdasarkan pendapatan tersebut dapat diketahui bahwa pendapatan keluarga nelayan tidak merata mulai dari kategori kurang cukup sampai dengan yang cukup. Kondisi ini menyebabkan ketika ada kegiatan ekonomi, misalnya mengolah ikan atau jualan ibu-ibu terkadang mengorbankan anaknya untuk tidak masuk sekolah

3. Data pengeluaran ibu-ibu tiap bulan paling dominan adalah Rp 1.500.000 - Rp 2.000.000 (7 orang/19.4\%), Rp 500000-1000000 (6 orang/16.7\%), Rp 1.000.000 - Rp 1.500 .000 (6 orang/16.7\%) dan yang kurang Rp 500.000 hanya 3 orang $(8.3 \%)$. Dengan demikian dapat diasumsikan ibu-ibu wali murid PAUD di RW II Tambak Wedi masih belum biasa menyisihkan uangnya untuk menabung karena pendapatan yang diperoleh habis untuk keperluan rutin bulanan.

4. Rata-rata ibu2 di PAUD RW II Tambak Wedi Surabaya masih memiliki satu anak yaitu sejumlah 14 orang (38.9\%), memiliki 2 anak (11/30.6\%), 3 anak sebanyak 5 orang (13.9\%) dan yang memiliki 4 anak sebanyak 3 orang atau $8.3 \%$. Berdasarkan data ini diketahui bahwa masih banyak ibu yang baru memiliki anak, sehingga dapat dipahami bahwa mereka masih belum punya pengalaman mendidik anak. Hal tersebut nampak ketika wawancara, ibu-ibu menanyakan bagaimana caranya mereka menghadapi anak yang banyak bertanya, anak banyak tingkahnya, suka corat-coret di dinding tembok. Ia juga bertanya bagaimana agar ia dapat meredakan emosi ketika menghadapi anak-anaknya, karena saat ini ia akan marah-marah ketika anak rewel atau bahkan mencubit atau memukulnya jika anaknya tidak bisa diberitahu.

5. Ibu-ibu di PAUD RW II Tambak Wedi sebanyak 15 orang $(41.7 \%)$ sudah biasa memberikan makanan yang berupa nasi sayur ikan laut dan nasi dengan ikan. Berarti ibu-ibu tersebut sudah biasa memberikan ikan laut sejak dini. Sedangkan sebanyak 18 ibu (54.54\%) masih belum membiasakan anaknya makan ikan sejak dini. Mereka membiasakan anaknya makan nasi dan telur sebanyak 6 ibu (16.7\%), nasi sayur tahu tempe $5 \mathrm{ibu}(13.9 \%)$, nasi tahu tempe sebanyak 4 ibu (11.1\%), nasi sayur asam 2 ibu (5.6\%) dan nasi dan ayam $1 \mathrm{ibu}(2.8 \%)$. Berdasarkan data ini maka masih perlu dilakukan penyuluhan tentang pentingnya anak-anak sejak dini dibiasakan makan ikan dan sayur. Selain ikan bergizi tinggi, juga mudah didapatkan di daerah Tambak Wedi karena pada umumnya orang tuanya adalah nelayan, sehingga ikannya masih segar.

6. Ibu-ibu juga telah membiasakan anaknya makan buah sejak anak dini yaitu sebesar $50 \%$ atau 18 ibu-ibu, 9 ibu-ibu (25\%) kadang-kadang memberikan buah pada anak-anak kadang tidak dan yang jarang memberikan buah sebanyak $6 \mathrm{ibu}(16.7 \%)$. 
7. Ibu-ibu juga menunjukkan mereka membiasakan memberi susu pada anaknya sebanyak 19 ibu (52.8\%), ibu-ibu yang kadang memberi susu kadang tidak sebanyak 10 ibu $(27.8 \%$, dan yang jarang memberi susu hanya 1 ibu $(2.8 \%)$ dan yang tidak pernah memberi sebanyak 3 ibu (8.3\%). Hal ini menunjukkan ibu-ibu sudah bagus kesadarannya untuk memberikan susu pada anaknya, hanya tinggal $11.1 \%$ saja yang masih perlu didorong untuk memberikan susu pada anaknya.

8. Ibu-ibu orang tua PAUD RW II Tambak Wedi suka memberikan jajanan roti atau biskuit sebanyak 24 orang (66.7\%), suka memberi kue basah 4 orang (11.1\%) dan hanya 5 orang (13.9\%) memberi jajan berupa ciki-cikian. Dengan demikian dapat disimpulkan bahwa ibu-ibu telah mengenalkan jajanan yang cenderung sehat pada anaknya.

9. Berdasarkan tempat tinggal, sebagian besar ibu-ibu sudah memiliki Rumah sendiri, yaitu 27 ibu (75\%) sedangkan $25 \%$ masih kontrak, kos atau tinggal bersama orang tua. Atas dasar ini menunjukkan ibu-ibu secara ekonomi sudah cukup mapan karena telah memiliki tempat tinggal sendiri.

\section{Sikap Ibu terhadap PAUD.}

Sikap ibu terhadap PAUD menunjukkan bahwa sebanyak 9 ibu (25\%) bersikap positif terhadap PAUD, 10 orang (30.30\%) sikap terhadap PAUD termasuk kategori sedang dan ibu-ibu yang sikapnya kurang positif terhadap PAUD sebanyak 14 orang (46.66\%). Dan dari skala sikap ibu terhadap belajar di PAUD diketahui juga bahwa ibu-ibu sebenarnya tahu bahwa PAUD itu tempat belajar bagi anakanak usia DINI dan ia juga akan memasukkan anaknya di PAUD, namun ia masih kurang suka jika anaknya belajar di PAUD hanya bermain-main saja. hal tersebut dapat dilihat dari data bahwa pengetahuan ibu tentang PAUD nilai rata-rata sebesar 5.6, aspek psikomotor yakni berupa tindakan untuk memasukkan anak ke PAUD, mengikuti kegiatan di PAUD sebesar 5.4. sedang kan aspek afeksi yang berupa ibu senang kegiatan anak di PAUD sebesar 4.8. Hal ini menunjukkan bahwa ibu-ibu di PAUD RW II sikapnya terhadap PAUD masih belum baik karena menganggap PAUD merupakan tempat bermain bagi anak-anak, bukan sebagai tempat belajar. Akibatnya ibu-ibu jika sedang sibuk bekerja atau ada aktifitas lain anak-anaknya tidak akan diantar untuk PAUD. Selain itu ibu-ibu masih menganggap di PAUD anak-anak tidak diajari menulis, berhitung atau membaca. Jadi tolok ukur ibu-ibu anak-anak belajar jika anak bisa membaca, menulis ataupun berhitung. Padahal PAUD merupakan Pendidikan non formal yang sifatnya mengembangkan aspek motorik kasar, motorik halus, melatih kepekaan pancaindera, mengembangkan Bahasa, social, emosi dan pengetahuan anak usia dini. Sehubungan dengan hal tersebut maka penyuluhan tentang aktifitas belajar di PAUD perlu disosialisasikan dengan baik dan orang tua perlu dilibatkan dalam pembelajaran anak agar dapat menindaklanjuti di Rumah.

\section{Kegiatan Kerjasama Ibu dan Anak}

Kegiatan ini memberikan gambaran stimulasi anak usia dini yang dapat dilakukan ibu dan anak di rumah dengan menggunakan bahan-bahan yang sederhana namun bertujuan untuk melatih kemampuan sensorik anak, yaitu kegiatan meremas kertas, dan menempel benda-benda kecil di kertas. Dan ada pemberian reward kepada anak dan ibu yang benar-benar mau berlatih dan melatih kemampuan sensorik anak dengan sabar dan telaten serta hasil kerja anak secara mandiri. Sedangkan jika dikaitkan dengan pendapat Grotberg (1979) bahwa tugas orangtua (Parental Role) dalam hubungannya dengan proses pendidikan anak adalah memberikan stimulasi edukasi (educational stimulation) dan dukungan emosi (emotional support). Stimulasi edukasi adalah pemberian kesempatan pada anak untuk dapat mengembangkan potensi dirinya baik secara emosional maupun intelektual, penyediaan sarana dan prasarana belajar, seperti buku-buku, alat permainan, serta pemberian kesempatan bagi anak untuk dapat bereksplorasi pada lingkungan yang lebih luas. Dukungan emosi dimaksudkan sebagai hubungan interpersonal antara anak dan orangtua.

\section{PENUTUP}

\section{Kesimpulan}

Sikap positif dan pemahaman ibu-ibu wali murid PAUD RW II Tambak Wedi terhadap pentingnya anak belajar di PAUD meningkat. Ibu-ibu memperoleh gambaran stimulasi anak usia dini yang dapat dilakukan ibu dan anak di rumah dengan menggunakan bahan-bahan yang sederhana namun bertujuan untuk melatih kemampuan sensorik anak, yaitu kegiatan meremas kertas, dan menempel benda-benda kecil di kertas (misalnya biji-bijian (jagung, kedelai, beras, kacangkacangan)).

\section{Saran}

Mengingat besarnya manfaat kegiatan pengabdian pada masyarakat ini, maka selanjutnya perlu:

1. Mengadakan penyuluhan serupa pada ibu-ibu di PAUD lain di wilayah pesisir Surabaya.

2. Adanya kesinambungan dan monitoring program pasca kegiatan pengabdian ini sehingga ibu-ibu wali PAUD benar-benar dapat memahami pentingnya Pendidikan PAUD dan meningkatkan keterlibatannya dalam Pendidikan anaknya. 


\section{DAFTAR PUSTAKA}

Adilla, S. 2010. Pentingnya Pendidikan Anak Usia Dini. Bumi Aksara Bandung.

Azwar, S. 2000. Sikap Manusia. Yogyakarta: Pustaka Pelajar.

Gardner, Sebastian, 1999. Kant and the Critique of Pure Reason, London: Routledge.

Grotberg, Edith H.1995.A Guide to Promoting Resilience in Children: Strengthening the Human Spirit. Den Haag: Bernard van Leer Foundation.

Hasan, M. 2009. Pendidikan Anak Usia Dini (PAUD). Diva Press. Yogyakarta.
Hasenstab.M.S. and J.S. Horner. 1982. Comprehensive intervention with hearing impaired infants and preschool children. Rockville: aspen system.

Hasnidah. 2014. Analisis Kebutuhan Anak Usia Dini. Jakarta: Luxima Metro Media.

Mansur, Pendidikan Anak Usia Dini Dalam Islam, Yogyakarta: Pustaka Pelajar, 2005.

Morrison, George S. 2012. Dasar-Dasar Pendidikan Anak Usia Dini. Jakarta: Indeks.

Sujiono, Yuliani. 2011. Konsep Dasar Pendidikan Anak Usia Dini. Jakarta: PT Indeks. 